\title{
Is Reading Comprehension Taken for Granted? An Analysis of Austrian Textbooks in Fourth and Sixth Grade
}

\author{
Susanne Seifert ${ }^{1}$
}

Accepted: 7 January 2021 / Published online: 19 January 2021

(c) The Author(s) 2021

\begin{abstract}
The range of teaching materials now available is becoming increasingly diverse. Despite this, however, the use and influence of textbooks in teaching still remains very high. When instructing reading comprehension, teachers often use textbooks as the basis for teaching in language lessons. Establishing a good match between textbooks and the skills to be acquired is therefore essential. In this paper, I investigate whether textbooks used in Austrian schools can adequately support the teaching of reading comprehension skills. Since reading comprehension is the basis for acquiring knowledge in all subjects, science textbooks are examined in addition to (German) language lesson textbooks. Thus, the content pages of four language textbooks and four science textbooks for fourth and sixth grade were analysed in terms of five different categories, i.e. general structural setup, learning goals, text types, text structures, and activities. The results reveal clear variations with respect to learning goals in language textbooks. For example, the extent to which reading comprehension is addressed ranges from 13.64 to $69.70 \%$, depending on the book used. Although not addressed as a learning goal in the science textbooks, reading comprehension is often presupposed, especially in sixth grade. While the instruction of reading comprehension ought to entail coverage of reading strategies, this is often neglected, or only dealt with indirectly. Given the diversity of textbooks analysed, it seems all the more important to stress that teachers should: 1) clarify the goals and teaching strategies of a book before using it, 2) become aware of strategies that support the development of students' reading comprehension, and 3) use textbooks as a complementary (and not sole) tool to support reading comprehension in all subjects.
\end{abstract}

Keywords Textbook · Reading comprehension · Reading strategies · German language · Science $\cdot$ Teacher training

Susanne Seifert

susanne.seifert@uni-graz.at

1 Institute for Educational Research and Educational Professionalization, Inclusive Education Unit, University of Graz, Merangasse 70/2, 8010 Graz, Austria 


\section{Introduction}

In modern societies, a relatively high value is placed upon reading ability. In everyday life, and in an increasingly digitalized world, numerous situations arise which require reading comprehension skills when attempting to obtain information. Reading comprehension also forms the basis for independent acquisition of knowledge in school and is thus also a clear prerequisite for achieving success in almost all school subjects. The development of reading comprehension is therefore something which is closely cultivated from the very beginning of schooling. However, as revealed by the large-scale reading assessment study, the Progress in International Reading Literacy Study (PIRLS) of 2016, after four years of schooling, $15 \%$ of Austrian students (typically aged 10) can only read either at, or below, a basic level of reading competence (Wallner-Paschon et al. 2017). Such a level entails the ability to locate, process and use important information in written texts (Mullis et al. 2009). In addition, prominent long-term studies in Austria (e.g., Salzburg long-term study: Landerl \& Wimmer 2008; Vienna long-term study: Klicpera \& Gasteiger-Klicpera 1993) show that poor reading abilities exhibit a clear tendency to persist.

Reading comprehension, defined as the ability to understand the meaning of a written word, sentence or text (Perfetti et al. 2005), involves processes at different hierarchical levels (e.g., Mullis \& Martin 2015) and is influenced by both psychological (e.g., motivation, learning style) and ecological factors (e.g., classroom and home environment) (see Component Model of Reading, CMR; Aaron et al. 2008; Joshi \& Aaron 2011). Considering the ecological component in the CMR, among other things, both teacher instructional practices as well as textbook content can affect the development of reading comprehension (Beerwinkle et al. 2018; Joshi et al. 2009). The focus of the present study is on textbooks, as these are viewed as being an important resource in the instruction of reading comprehension in Austrian schools.

\subsection{Reading Comprehension Instruction in Austria}

In Austria, the language of instruction is German, thus reading instruction primarily takes place in German language lessons. As in many other European countries, the ability to successfully acquire reading comprehension skills has a great impact on a student's future school career (Breit et al. 2016). The national curriculum for German lessons (issued by the Austrian Federal Ministry of Education, BMBWF, and available on its homepage, BMBWF 2003) has thus made reading ability one of the core competences that has to be achieved within German lessons. This holds for both primary and secondary schooling. Although basic reading skills are taught throughout primary school (the first four years of schooling, ages 6 to 10), at the secondary level (i.e. from the age of 10), a focus is also placed on developing a child's ability to read and understand texts (in either print or digital form) (BWBWF 2018, 2020).

In addition to the national curriculum on German lessons, the principle decree on reading education, also published by the BMBWF (BMBWF 2013), also sets out the tasks of reading education with respect to all other subjects. Above all, the decree states that reading instruction needs to be cross-curricular, and relevant for all subjects taught in school, i.e. not only for German language lessons. Consequently, all teachers (even those engaged in fields outside German language teaching) need to develop the appropriate attitudes and skills in education and training that will enable them to support the acquisition of reading 
skills. The official decree provides explicit examples of how teachers may go about promoting reading skills. One of these recommendations is that students should be offered a differentiated range of texts in terms of text genre and function (e.g., expository texts, fictional texts, texts for entertainment, suspense, relaxation, information, etc.). The decree also attaches great importance to factual reading (the reading of expository texts), especially during the transition from primary to secondary school (grade 4, age 10) and at other points in the school career affecting school selection (a pupil's ability to acquire factual information through reading has a strong influence on school selection) (BMBWF 2013). Another recommendation in the decree focuses on reading strategies: "Reading strategies should be taught at each reading level and in each subject, with special reference to the specific sign systems and terminology of the respective subject (e.g., mathematical information, scientific formulae, etc.). Reading strategies include activating prior knowledge; clarifying text structure based on content or formal categories; visualizing text; separating the essential from the unimportant; opening up unknown words; asking questions in order to search for specific information from the text." (BMBWF 2013, para. "Making reading strategies conscious and practicing them"). In addition to the above decree, the importance of implementing reading strategies for instructing reading comprehension is also highlighted in the 2012 Austrian National Education Report (Schabmann et al. 2012). According to Schabmann et al. (2012), conveying structural and text-related comprehension strategies is one of the two main pillars comprising comprehension instruction (the other is expanding children's vocabulary). Additionally, reading strategies are clearly an important tool in selfregulated reading (Philipp 2015).

As seen in the large-scale studies PIRLS 2016 (Schmich et al. 2017) and PISA 2009 (Schwantner \& Schreiner 2010), while a focus is placed upon reading comprehension in both primary and secondary schools in Austria, in contrast to other countries (PIRLS: EU countries; PISA: OECD countries), Austrian students spend relatively little time on reading-related activities.

The PIRLS study (2016) also examined the experience of Austrian children with respect to reading instruction. In the context of PIRLS, Schmich and colleagues (2017) examined, for example, the text types read in grade 4, noting that, in general, factual and literary texts are regularly read by fourth graders (aged 10). There are no differences in the use of shorter texts (expository and narrative) between Austria and the EU countries. Additionally, an analysis of the use of reading comprehension strategies in Austrian reading instruction revealed a clear discrepancy between Austria and the EU average. For example, it was found that while almost half of all students in EU countries systemically develop new vocabulary with their teacher on a daily basis, only about $25 \%$ of Austrian students do so (Schmich et al. 2017). There is a similar discrepancy when it comes to the teaching of strategies used in summarizing the main statements of a text. While almost one third of Austrian students meet these strategies (almost) daily, and almost half at least weekly, the EU average shows more students summarizing main statements (almost) daily (Schmich et al. 2017). Summarizing main statements, however, is not the only strategy used to teach reading comprehension in Austrian classrooms. Two other strategies are also important: searching for information within a text, and explaining one's understanding of what has been read. More than $85 \%$ of the Austrian fourth graders practice each of these two strategies at least once a week (Schmich et al. 2017). Yet in other EU countries teachers encourage strategies such as predicting the action of a text, describing its structure or style, and determining the author's perspective, more frequently than is the case in Austria (Schmich et al. 2017). Similarly, while the use of a text's structure is seen as an important strategy for enhancing reading comprehension skills-particularly in the context of the United 
States (Hebert et al. 2016; Meyer 1975; Wijekumar et al. 2017) — this strategy is not often employed by teachers in Austria. For example, $75 \%$ of Austrian fourth graders reported that they practice such a strategy either never, or not more than twice a month, compared to $41 \%$ of students throughout the EU (Schmich et al. 2017).

\subsection{Textbooks as an Influential Source of Instruction}

Although today's teachers have access to a wide range of educational media for their lessons, school textbooks are still often used for teaching (Doll \& Rehfinger 2012; Knight 2013; Stern \& Roseman 2004). As seen in a variety of international studies concerning a number of different subject areas, the influence textbooks have on teachers and their teaching remains quite high (e.g., Heinze 2005; Irez 2009; Nicol \& Crespo 2006; Richards 2014; Roth et al. 2006). For example, textbooks act as a guide for teachers when choosing topics or when deciding how they may be taught (Valverde et al. 2002). They also impact students' learning outcomes (e.g., mathematical achievements: van den Ham \& Heinze 2018).

Since, by necessity, textbook authors engage in interpreting a specific curriculum and transforming it into texts and concrete tasks that teachers and students may then carry out, textbooks may be perceived as acting as mediators between the curriculum intended by policy makers and the curriculum implemented by the teachers (Valverde et al. 2002). In this way, textbooks may thus provide support for teachers in instructing reading comprehension as prescribed by the national curriculum. However, as textbook authors also have a certain amount of freedom in how they set about implementing the national curricula, textbooks may in fact be very different from each other. In addition, textbooks often only offer rather limited coverage of the topics or tasks that need to be addressed (Kahl 2000; Maijala \& Tammenga-Helmantel 2017; Richards 2014). In terms of reading comprehension, for example, Beerwinkle and colleagues (2018) showed that language lesson textbooks in the United States covered skills and strategies addressing reading comprehension only rather sporadically.

\section{Present Study}

\subsection{Aims and Purpose}

In the present analysis, textbooks are perceived as being instruments that teachers often rely upon when teaching diverse content. This is also taken to be true with respect to reading comprehension instruction. As pointed out above, reading comprehension instruction (in Austria) is a major part of reading instruction, taking place in primary school German language lessons and continuing in secondary school as well. The present study thus examines books in the last year of primary school (grade 4, where children are typically aged 10 ), and books in the second secondary school grade (grade 6, children typically aged 12). This approach allows one to investigate whether there are clear differences in the focus of reading comprehension with respect to the transition from primary to secondary school.

In addition, the national decree on reading education prescribes that reading comprehension instruction is a matter of concern not only in language lessons, but also in other subject areas. Hence, both German textbooks (used in language lessons) and subject matter textbooks (specifically, science textbooks) were analysed in terms of the extent to which 
they address reading comprehension in order to assess how they do or do not support the teaching of reading comprehension in Austria.

The relevant textbooks for these two subject areas and grades were thus analysed and compared in terms of the following five categories: (a) the textbook's structural setup (e.g., number of texts, text ratio, task ratio); (b) learning goals (e.g., reading comprehension, vocabulary); (c) included text types (e.g., narratives, expository texts); (d) text structures (e.g., comparison, cause and effect); and (e) instructional strategies and activities (e.g., reading for fluency, direct retrieval of facts). By analysing texts for evidence of reading comprehension content, or the lack thereof, one can determine whether the textbooks include instruction directly addressing reading comprehension skills or whether reading comprehension skills are required to complete tasks in the textbook. Specifically, analysing category a) allows us to have a closer look at the relation of texts and tasks to content, and thus to draw conclusions concerning the amount of text entailed in reading comprehension. Analysing category b), learning goals, shows us whether the textbooks highlight reading comprehension or not. The analysis of the categories c), d) and e) is intended to reveal whether the textbooks examined can be used to teach reading comprehension in a way which meets the criteria prescribed by the national curriculum and by the relevant official decree. In addition to examining the connection to reading strategies required in the Austrian curriculum, this also allows us to ascertain whether other internationally recognised reading strategies can be taught through Austrian textbooks, for example the strategy of following the organisational structure of a text in order to identify the most important facts (Hebert et al. 2016; Meyer 1975).

\section{Method}

This study is part of a comparative European study on school textbook analyses. This was initiated by an international team of researchers from COST Action IS1401 (COST 2019) in 2017 in Zagreb. A subsequent meeting was then held at the First Literacy Summit in Porto, Portugal (COST 2018). This was where the final decisions were made concerning the kind of textbooks and codes to be used for comparative analysis.

\subsection{Textbooks Analysed}

Given that reading comprehension instruction primarily takes place in language lessons, the members of the international team of COST Action 1401 decided to analyse language textbooks (of the respective national language) (COST 2018). Science textbooks (i.e. textbooks used in the subject biology) were also selected for analysis so that language text results and results from a non-language subject area could be compared. A decision was also made to analyse fourth and sixth grade textbooks since the transition from primary to secondary education was of interest to all researchers.

For the present study (in Austria), textbook selection was based on a list provided by the School Textbook Initiative. This list identified the five most frequently sold books in each of the four categories listed above for the 2017/2018 school year. The School Textbook Initiative is financed by the Federal Ministry of Education, Science and Research and provides students with required educational aids free of charge. In each school year, the schools choose the books for each student from a list of approved books. All such material complies with national curricula and educational requirements. For the 2017/18 school year, 
there were 23 German books for Grade 4, 17 German books for Grade 6, 6 science books for Grade 4 (subject general science and social studies), and 22 science books for Grade 6 (subject biology). In order to select the most popular books from this list, the author wrote to the School Textbook Initiative and asked for a list of the most frequently sold texts. The School Textbook Initiative provided a list of the five most frequently sold books in each category to the author. This may thus be seen as a reliable source for identifying the most popular and frequently used books in Austrian schools. From this list, the author then chose two of the books from each category, to which publishers provided online access. When possible, from different publishing houses were selected for each category. Thus, two fourth grade German primary school books (Freund et al. 2016; Koppensteiner et al. 2018) and two sixth grade secondary school books (Bulling et al. 2016; Pramper \& Leb 2012) were selected, as well as two fourth grade primary school general science and social studies books (Barnitzky et al. 2011; Bertsch et al. 2016) and two sixth grade secondary school biology books (Drexler et al. 2016; Schermaier \& Weislö 2013).

\subsection{Unit of Analysis}

Only pages containing content were analysed. The table of contents, index, appendices, and other extra information (e.g., word lists, explanations on research on the internet, solutions etc.) were excluded from the analysis. The relative proportions of text and tasks typically varied throughout the content pages.

All textbooks were thematically organised into chapters. For the most part, each chapter contained several sub-chapters dealing with different aspects of the topic and targeting different goals. Thus, for the purposes of the present analysis, taking whole chapters as the unit of analysis was not appropriate. It was also necessary to choose a unit of analysis below that of chapter level to quickly identify discrepancies in inter-rater reliability. Each chapter contained individual sub-chapters, or sections. As activities and goals can be more clearly assigned to specific sections, the latter unit of analysis was chosen in order to make the analysis cleaner and more comprehensible. The separate content pages were thus analysed independently for each section.

\subsection{Categories and Codes}

The researchers of COST Action 1401 (COST 2018) decided to use the analysis criteria proposed by Beerwinkle and colleagues (2018). In accordance with this decision, the present author refined the criteria so as to suit the national specifics in the chosen textbooks. Thus, every section was analysed in terms of five different categories: the structural setup of the textbook, the general learning goal of the sections, text types used in the sections, text structures seen in the texts, and the instructional strategies and activities (tasks) involved in the sections.

The first criterion was needed to identify each textbook's structure. As this presents general information on the textbook, results for this criterion are presented first in all sub-analyses.

Texts obviously provide the basis for analysis for the categories text type and text structure. However, the textbooks contain many short texts of up to five sentences. These may be used to open the topic of the page (e.g., "Sometimes it is not easy to decide whether a secret is good or bad.", Barnitzky et al. 2011, p. 16), to offer reading tips (e.g., "Imagine the poem with all your senses.", Koppensteiner et al. 2018, p. 40) or to pinpoint items of 
significance (e.g., "Advertising slogans are short, catchy slogans that are easy to remember. They are often incomplete sentences.", Pramper \& Leb 2012, p. 45). As very short passages are not likely to be used as a source for reading comprehension, for the purposes of the present study, a text passage was analysed only when it had five sentences or more.

Textbook's structural setup The structural setup varied considerably across the books analysed. There were big differences with respect to the number of content pages, chapters, and sections, as well as with respect to the number of texts and tasks included in each book. For example, some sections in one textbook might contain only one text with more than 8 tasks, whereas in other textbooks there might be more than 10 texts per section and 10 corresponding tasks. To help portray these differences, the textbooks were coded in terms of the number of content pages, chapters, sections, texts, and tasks. As a measure of the amount of texts and tasks in relation to the content pages, the ratios of text and task to content was calculated. The text ratio was calculated by dividing the total number of counted text units by the number of content pages identified, and the task ratio was calculated by dividing the total number of counted tasks by the number of content pages identified. This gives an indication of the extent to which a particular textbook relies on texts and/or tasks.

Learning goal In this category, the learning goal of each section was identified. One out of 16 different predefined goals (codes) was identified (e.g., comprehension, grammar, orthography, writing a narrative/expository/persuasive essay). With respect to the German language textbooks, the goal was mostly explicitly mentioned in the form of a section title. Some of the sections in these books were designed as a summary or repetition of different sections belonging to a chapter and thus combined more than one of the goals. In the science textbooks, the goals were, in most cases, not explicitly mentioned and thus needed to be inferred. If none of the predefined goals applied (which was primarily the case when there was more than one general learning goal identifiable in a section), the designation 'other' was chosen. The percentage of learning goals (in relation to the total number of sections) was calculated for each textbook.

Text type In this category, the types predefined by the COST 1401 researcher team were narrative, expository and biographical texts. When a text was found to be of some other type (e.g., poems, letters, tongue twisters, comics, interviews, advertising texts, newspaper articles, jokes), it was coded as 'other'. The percentage of text types (in relation to the total number of texts of at least five sentences) was calculated for each book.

Text structure As predefined by the international researcher team, texts were analysed with respect to whether a text structure could be identified in terms of Meyer's (1975) five different text structures: comparison, cause and effect, problem and solution, sequence and description. In Austria, text structure strategy training is not well established and not part of daily teaching activity (see above, Schmich et al. 2017). Nevertheless, making use of this category was still helpful in the present analysis as it allowed for evaluation of whether the teaching of such structures and of text structure strategy might at all be possible using the given textbooks. As expected, the analysis revealed that the textbooks do not explicitly work with text structures. This meant that the structures needed to be inferred by the present author. Thus, the text was assigned a text structure when an organisational pattern (e.g., a list of several consecutive steps for the text structure "sequence") could be ascribed to a text, or when specific signalling words (e.g., "if-then", "reasons why", and "as a result", for the text structure "cause and effect") were mentioned (e.g., Akhondi et al. 2011). Mostly, none of these structures could be identified separately in a text. Narratives, in particular, tend to have more than one structure since they contain elements of 'sequence', 'description' or/and 'comparison', 'problem and solution' or 'cause and effect' simultaneously. In such cases, no text structure was chosen. This decision was based on the 
fact that instruction relies upon clear identification of text structure. For example, when two or more structures are combined, signalling words that help to identify the structure of a text and provide a framework for understanding the content (Roehling et al. 2017) need to be unambiguously assigned to one structure. Where this is not the case, they are misleading. In the present analysis, in addition to presenting the identified text structures, the count and percentage of texts with (unambiguous) text structures (in relation to the number of texts in the specific book) were calculated for each textbook.

Instructional strategies and activities For this category, each task in the sections was coded. One out of 17 different strategies or activities, again predefined by the international researcher team (COST 2018), was identified for each task (e.g., reading for fluency, direct retrieval of facts, generating inferences, elaborating on a topic, relevance to self, explaining vocabulary). Where more than one strategy or activity was addressed within one task, the predominant activity or strategy was selected, or when different activities or strategies were included within one task, the task with the highest competence requirements was chosen (e.g., elaboration on a topic requires higher competences compared to direct retrieval of information, see also Mullis \& Martin 2015). If none of these predefined strategies or activities was identified, 'other' was chosen (e.g., listening comprehension, visual differentiation). The percentage of instructional strategies and activities (in relation to the total number of tasks) was then calculated for each textbook.

\subsection{Analysis Procedures}

All books were analysed by the present author. For purposes of verification, the author also drew on the help of two master's students (Master's in Inclusive Education, University of Graz). These students were first asked to familiarize themselves with the necessary analytical procedures and then to examine and code the first two chapters of all texts. A percentage of inter-rater agreement (reliability) between the author's codings and each of the students' codings was then calculated in Excel using the following formula described in Miles and Huberman (1994):

$$
\text { reliability }=\frac{\text { number of agreements }}{\text { number of agreements }+ \text { disagreements }}
$$

After coding the first textbook (Koppensteiner et al. 2018) for the first time, discussion between the present author and students revealed that the reliability figure for student 1 was only $56.25 \%$, while that for student 2 was only $59.37 \%$. The most discrepancies between the author's and student codings were found with respect to text counts and the categories for which texts are the basis of analysis (i.e. text type and text structure). The students counted partly texts of less than five words, leading to discrepancies with the present author's codings. In addition, as some activities were unclear for the students the respective allocations were often wrong. After discussing the discrepancies, the students coded the first two chapters of the textbook again, and also coded the first chapters of all the other textbooks. Depending on the book, $11.36 \%$ (Freund et al. 2016) to 53.33\% (Drexler et al. 2016) of each book was coded by the two students. There was then a match of over $80 \%$ across all categories between author and student codings, and this was true for both students. Once again, after reviewing results, discrepancies were discussed and minor corrections were made to the counts or percentages of either authors or students' codings. Subsequently, the present author analysed all the remaining chapters of the eight textbooks. 


\section{Results}

The results of the textbook analysis are displayed separately for language textbooks and science textbooks, and also separately for the fourth (aged 10) and sixth grade (aged 12). The results regarding the category learning goals are presented first, followed by the categories text types, text structure, and instructional strategies and activities. In terms of the categories learning goals, text types, text structures, and instructional strategies and activities, only those items which were identified in at least one book are listed in the tables. The codes in the tables were ordered according to their average frequency of occurrence.

\subsection{German Language Textbooks}

\subsubsection{Fourth Grade}

The structural setup used in the two grade 4 German language textbooks is quite similar (see Table 1). The Freund et al. (2016) textbook is more comprehensive and contains more content pages, chapters, sections and texts. In view of the lower number of pages in the Koppensteiner et al. (2018) textbook, there is also a corresponding reduction in number of chapters, sections and texts. Compared to Koppensteiner et al. (2018), however, the text ratio and tasks ratio are higher.

Looking at both books together, the most frequent learning goal of the sections was 'comprehension', followed by 'grammar', 'orthography' and 'vocabulary' (see Table 2). However, when looking at the books individually, the picture becomes less clear. The Koppensteiner et al. (2018) textbook concentrates almost exclusively on reading comprehension. It was found that nearly $70 \%$ of the sections in the text addressed this learning goal, while most of the other goals, apart from 'vocabulary', i.e. grammar, orthography, etc., proved to be only marginally significant, if at all. In contrast, in the other textbook (Freund et al. 2016), the learning goals 'grammar' and 'orthography' were more prominent than 'comprehension'.

Turning to the category text types, the most frequent text types in the grade 4 language textbooks were narratives, followed by expository texts and then other text types (e.g., poems, letters). Again, looking at the books individually, a clear contrast can be found in terms of their respective proportions of narrative and expository texts (see Table 3 ). While Freund et al. (2016) focuses on narrative texts, Koppensteiner et al. (2018) includes more expository texts.

Table 1 Structural setup of grade 4 language textbooks

\begin{tabular}{llll}
\hline & $\begin{array}{l}\text { Freund } \\
\text { et al. 2016 }\end{array}$ & $\begin{array}{l}\text { Koppensteiner } \\
\text { et al. 2018 }\end{array}$ & $\begin{array}{l}\text { Aver- } \\
\text { age both } \\
\text { books }\end{array}$ \\
\hline Number of content pages & 107 & 74 & 90.5 \\
Number of chapters & 20 & 9 & 14.5 \\
Number of sections & 88 & 33 & 60.5 \\
Number of texts & 62 & 30 & 46 \\
Ratio of text to content & 0.58 & 0.41 & 0.49 \\
Number of texts & 300 & 113 & 206.5 \\
Ratio of tasks to content & 2.8 & 1.53 & 2.17 \\
\hline
\end{tabular}


Table 2 Numbers and percentages for learning goals in the grade 4 language textbooks

\begin{tabular}{|c|c|c|c|c|c|}
\hline \multirow[t]{2}{*}{ Learning goal } & \multicolumn{2}{|c|}{ Freund et al. 2016} & \multicolumn{2}{|c|}{$\begin{array}{l}\text { Koppensteiner } \\
\text { et al. } 2018\end{array}$} & \multirow{2}{*}{$\begin{array}{l}\text { Average } \\
\text { both books } \\
\%\end{array}$} \\
\hline & $\mathrm{N}$ & $\%$ & $\mathrm{~N}$ & $\%$ & \\
\hline Comprehension & 12 & 13.64 & 23 & 69.70 & 48.49 \\
\hline Grammar & 17 & 19.32 & 0 & 0 & 9.66 \\
\hline Orthography & 17 & 19.32 & 0 & 0 & 9.66 \\
\hline Vocabulary & 0 & 0 & 5 & 15.15 & 7.58 \\
\hline Writing a narrative essay (also: writing letters) & 10 & 11.36 & 0 & 0 & 5.68 \\
\hline Writing an expository essay & 5 & 5.68 & 0 & 0 & 2.84 \\
\hline Critical thinking & 2 & 2.27 & 1 & 3.03 & 2.65 \\
\hline \multicolumn{6}{|l|}{ Narrative plot/character/ } \\
\hline theme & 3 & 3.41 & 0 & 0 & 1.71 \\
\hline Fluency & 0 & 0 & 1 & 3.03 & 1.52 \\
\hline Argumentation & 2 & 2.27 & 0 & 0 & 1.14 \\
\hline Writing a persuasive essay (e.g., advertisement) & 1 & 1.14 & 0 & 0 & 0.57 \\
\hline Conceptual knowledge & 1 & 1.14 & 0 & 0 & 0.57 \\
\hline Other & 18 & 20.45 & 3 & 9.09 & 14.77 \\
\hline
\end{tabular}

Table 3 Numbers and percentages for text types in grade 4 language textbooks

Table 4 Numbers and percentages for texts with a text structure in grade 4 language textbooks

\begin{tabular}{|c|c|c|c|c|c|}
\hline \multirow[t]{2}{*}{ Text type } & \multicolumn{2}{|c|}{ Freund et al. 2016} & \multicolumn{2}{|c|}{$\begin{array}{l}\text { Koppensteiner } \\
\text { et al. } 2018\end{array}$} & \multirow{2}{*}{$\begin{array}{l}\text { Average } \\
\text { both books } \\
\%\end{array}$} \\
\hline & $\mathrm{N}$ & $\%$ & $\mathrm{~N}$ & $\%$ & \\
\hline Narrative & 34 & 54.84 & 9 & 30 & 42.42 \\
\hline Expository & 11 & 17.74 & 17 & 56.67 & 37.21 \\
\hline Other & 17 & 27.42 & 4 & 13.33 & 20.38 \\
\hline
\end{tabular}

\begin{tabular}{|c|c|c|c|c|c|}
\hline \multirow[t]{2}{*}{ Text structure } & \multicolumn{2}{|c|}{$\begin{array}{l}\text { Freund et al. } \\
2016\end{array}$} & \multicolumn{2}{|c|}{$\begin{array}{l}\text { Koppensteiner } \\
\text { et al. } 2018\end{array}$} & \multirow{2}{*}{$\begin{array}{l}\text { Average } \\
\text { both books } \\
\%\end{array}$} \\
\hline & $\mathrm{N}$ & $\%$ & $\mathrm{~N}$ & $\%$ & \\
\hline Sequence & 17 & 27.42 & 5 & 16.67 & 22.05 \\
\hline Description & 8 & 12.9 & 3 & 1 & 6.95 \\
\hline Problem \& solution & 0 & 0 & 1 & 3.33 & 1.67 \\
\hline No text structure & 37 & 59.68 & 21 & 70 & 64.84 \\
\hline
\end{tabular}

In the grade 4 reading texts, only about $35 \%$ of all texts were identified as having a specific text structure (see Table 4). The most frequently identified text structure was 'sequence', followed by 'description'. The structure 'problem and solution' was found only once, this being in the Koppensteiner et al. (2018) textbook.

Many different instructional strategies were identified among the tasks contained within the two textbooks. The three most frequent ones were 'direct retrieval of facts', 'explain 
Table 5 Numbers and percentages for instructional strategies in grade 4 language textbooks

\begin{tabular}{|c|c|c|c|c|c|}
\hline \multirow[t]{2}{*}{ Instructional strategy } & \multicolumn{2}{|c|}{ Freund et al. 2016} & \multicolumn{2}{|c|}{$\begin{array}{l}\text { Koppensteiner et al. } \\
2018\end{array}$} & \multirow{2}{*}{$\begin{array}{l}\text { Average } \\
\text { both books } \\
\%\end{array}$} \\
\hline & $\mathrm{N}$ & $\%$ & $\mathrm{~N}$ & $\%$ & \\
\hline Direct retrieval of facts & 12 & 4 & 19 & 16.81 & 10.41 \\
\hline Explain vocabulary & 3 & 1 & 20 & 17.70 & 9.35 \\
\hline Generate inferences & 17 & 5.67 & 14 & 12.39 & 9.03 \\
\hline Description of entity & 20 & 6.67 & 10 & 8.85 & 7.76 \\
\hline Elaborate on a topic & 20 & 6.67 & 4 & 3.54 & 5.11 \\
\hline Activating background knowledge & 12 & 4 & 7 & 6.19 & 5.1 \\
\hline Utility/ Relevance to self & 17 & 5.67 & 3 & 2.65 & 4.16 \\
\hline Summarize the text & 9 & 3 & 4 & 3.54 & 3.27 \\
\hline T-chart & 16 & 5.33 & 1 & 0.88 & 3.11 \\
\hline Sequence & 7 & 2.33 & 2 & 1.77 & 2.05 \\
\hline Reading for fluency & 8 & 2.67 & 1 & 0.88 & 1.78 \\
\hline Concept Maps & 2 & 0.67 & 1 & 0.88 & 0.78 \\
\hline Compare \& Contrast & 3 & 1 & 0 & 0 & 0.5 \\
\hline Other & 154 & 51.33 & 27 & 23.89 & 37.61 \\
\hline
\end{tabular}

vocabulary', and 'generate inferences', followed by 'description of entity' and 'elaborate on a topic' (see Table 5). However, the two books vary in terms of their focus on respective strategies. The instructional strategy 'explain vocabulary' stands out the most, accounting for $17.7 \%$ of the identified strategies in Koppensteiner et al. (2018), but only for $1 \%$ in Freund et al. (2016). In Freund et al. (2016), more than half of the tasks were identified as 'other' since they were designed to foster competences other than reading (e.g., listening comprehension, visual differentiation, internet research, grammar).

\subsubsection{Sixth Grade}

Concerning structural setup, although the two grade 6 language textbooks are fairly similar in terms of number of content pages, the differences in the text ratio and tasks ratio are greater compared to those found in the grade 4 textbooks. The book of Pramper and Leb (2012), which had the smaller number of content pages, showed a high text ratio of 0.83 and a task ratio of 1.85 . In this book, it was frequently the case that more than one short text was presented on a single page. In contrast, in the textbook by Bulling et al. (2016), the opposite picture appears to be the case, with a text ratio of 0.39 , and a relatively high tasks ratio of 3.23. This may be explained by the fact that the latter textbook offers longer texts and quite often more than one page is needed to cover all the activities relating to the text (see Table 6).

As was also found in the grade 4 books, the most frequent learning goal was 'comprehension', followed by 'grammar', 'writing a narrative essay' and 'orthography' (see Table 7). While in the book by Bulling et al. (2016), 'fluency' was not a prominent learning goal, in the book by Pramper and Leb (2012), this learning goal was identified in 25\% of the sections, making it nearly as frequent as 'comprehension'.

The most frequent text types identified in the grade 6 language textbooks were narratives, followed by expository texts (see Table 8). 
Table 6 Structural setup of grade 6 language textbooks

\begin{tabular}{llll}
\hline & $\begin{array}{l}\text { Pramper \& } \\
\text { Leb, 2012 }\end{array}$ & $\begin{array}{l}\text { Bulling } \\
\text { et al. 2016 }\end{array}$ & $\begin{array}{l}\text { Aver- } \\
\text { age both } \\
\text { books }\end{array}$ \\
\hline Number of content pages & 120 & 155 & 137.5 \\
Number of chapters & 4 & 8 & 6 \\
Number of sections & 20 & 78 & 49 \\
Number of texts & 76 & 61 & 68.5 \\
Ratio of text to content & 0.83 & 0.39 & 0.61 \\
Number of texts & 222 & 501 & 361.5 \\
Ratio of tasks to content & 1.85 & 3.23 & 2.54 \\
\hline
\end{tabular}

Table 7 Numbers and percentages for learning goals in grade 6 language textbooks

Table 8 Numbers and percentages for text types in grade 6 language textbooks

Table 9 Numbers and percentages for texts with a text structure in grade 6 language textbooks

\begin{tabular}{|c|c|c|c|c|c|}
\hline \multirow[t]{2}{*}{ Learning goal } & \multicolumn{2}{|c|}{$\begin{array}{l}\text { Pramper } \\
\text { \& Leb } \\
2012\end{array}$} & \multicolumn{2}{|c|}{$\begin{array}{l}\text { Bulling } \\
\text { et al. } 2016\end{array}$} & \multirow{2}{*}{$\begin{array}{l}\text { Average } \\
\text { both books } \\
\%\end{array}$} \\
\hline & $\mathrm{N}$ & $\%$ & $\mathrm{~N}$ & $\%$ & \\
\hline Comprehension & 7 & 35 & 18 & 23.08 & 29.04 \\
\hline Grammar & 2 & 10 & 16 & 20.51 & 15.26 \\
\hline $\begin{array}{l}\text { Writing a narrative essay (also: } \\
\text { writing letters) }\end{array}$ & 1 & 5 & 12 & 15.38 & 10.19 \\
\hline Orthography & 2 & 10 & 8 & 10.26 & 10.13 \\
\hline Fluency & 5 & 25 & 0 & 0 & 12.5 \\
\hline Writing an expository essay & 1 & 5 & 2 & 2.56 & 3.78 \\
\hline Critical thinking & 1 & 5 & 1 & 1.28 & 3.14 \\
\hline Narrative plot/character/theme & 0 & 0 & 1 & 1.28 & 0.64 \\
\hline Other & 1 & 5 & 20 & 25.64 & 15.32 \\
\hline
\end{tabular}

\begin{tabular}{lllllll}
\hline Text type & \multicolumn{2}{l}{$\begin{array}{l}\text { Pramper \& Leb } \\
2012\end{array}$} & & \multicolumn{2}{l}{ Bulling et al. 2016 } & $\begin{array}{l}\text { Average } \\
\text { both books }\end{array}$ \\
\cline { 2 - 3 } \cline { 5 - 6 } & $\mathrm{N}$ & $\%$ & & $\mathrm{~N}$ & $\%$ & $\%$ \\
\hline Narrative & 38 & 50 & & 41 & 67.21 & 58.61 \\
Expository & 13 & 17.11 & & 15 & 24.59 & 20.85 \\
Other & 25 & 32.89 & & 5 & 8.20 & 15.05 \\
\hline
\end{tabular}

\begin{tabular}{|c|c|c|c|c|c|}
\hline \multirow[t]{2}{*}{ Text structure } & \multicolumn{2}{|c|}{$\begin{array}{l}\text { Pramper \& Leb } \\
2012\end{array}$} & \multicolumn{2}{|c|}{$\begin{array}{l}\text { Bulling et al. } \\
2016\end{array}$} & \multirow{2}{*}{$\begin{array}{l}\text { Average } \\
\text { both books } \\
\%\end{array}$} \\
\hline & $\mathrm{N}$ & $\%$ & $\mathrm{~N}$ & $\%$ & \\
\hline Description & 6 & 7.89 & 1 & 1.64 & 4.77 \\
\hline Sequence & 3 & 3.95 & 3 & 4.92 & 4.44 \\
\hline No text structure & 67 & 88.16 & 57 & 93.44 & 90.8 \\
\hline
\end{tabular}


Table 10 Numbers and percentages for instructional strategies in grade 6 language textbooks

\begin{tabular}{|c|c|c|c|c|c|}
\hline \multirow[t]{2}{*}{ Instructional strategy } & \multicolumn{2}{|c|}{ Pramper \& Leb 2012} & \multicolumn{2}{|c|}{ Bulling et al. 2016} & \multirow{2}{*}{$\begin{array}{l}\text { Average } \\
\text { both books } \\
\%\end{array}$} \\
\hline & $\mathrm{N}$ & $\%$ & $\mathrm{~N}$ & $\%$ & \\
\hline Elaborate on a topic & 18 & 8.11 & 39 & 7.78 & 7.95 \\
\hline Direct retrieval of facts & 4 & 1.80 & 55 & 10.98 & 6.39 \\
\hline Generate inferences & 13 & 5.86 & 28 & 5.59 & 5.73 \\
\hline Reading for fluency & 18 & 8.11 & 12 & 2.40 & 5.26 \\
\hline Activating background knowledge & 8 & 3.60 & 28 & 5.59 & 4.60 \\
\hline T-chart & 9 & 4.05 & 22 & 4.39 & 4.22 \\
\hline Explain vocabulary & 9 & 4.05 & 20 & 3.99 & 4.02 \\
\hline Utility/ Relevance to self & 7 & 3.15 & 10 & 2.00 & 2.58 \\
\hline Sequence & 0 & 0 & 10 & 2.00 & 1.00 \\
\hline Description of entity & 2 & 0.90 & 5 & 1.00 & 0.95 \\
\hline Concept Maps & 1 & 0.45 & 3 & 0.60 & 0.53 \\
\hline Compare \& Contrast & 1 & 0.45 & 3 & 0.60 & 0.53 \\
\hline Plot diagram & 1 & 0.45 & 3 & 0.60 & 0.53 \\
\hline Summarize the text & 0 & 0 & 2 & 0.40 & 0.20 \\
\hline Other & 131 & 59.01 & 261 & 52.10 & 55.56 \\
\hline
\end{tabular}

Only about $10 \%$ of all texts in the two books were identified as having a specific text structure (see Table 9). The text structures identified were 'sequence' and 'description'.

The two grade 6 language textbooks differ in terms of most frequent instructional strategy identified (see Table 10). The strategy 'elaborate on a topic' was frequently identified in both Pramper and Leb and in Bulling et al. (at 8.11 and $7.78 \%$, respectively). In the former book this frequency rate of $8.11 \%$ was also equal to that found for the strategy 'reading for fluency'. However, in the Bulling et al. textbook, the strategy 'direct retrieval of facts' was found to be even more frequent (see Table 10). In both books, again, more than half of the tasks were identified as 'other' since they were designed to foster competences other than reading (e.g., listening comprehension, internet research, grammar).

Table 11 Structural setup of grade 4 science textbooks

\begin{tabular}{llll}
\hline & $\begin{array}{l}\text { Bartnitzky } \\
\text { et al. 2011 }\end{array}$ & $\begin{array}{l}\text { Bertsch } \\
\text { et al. 2016 }\end{array}$ & $\begin{array}{l}\text { Aver- } \\
\text { age both } \\
\text { books }\end{array}$ \\
\hline Number of content pages & 61 & 56 & 58.5 \\
Number of chapters & 6 & 7 & 6.5 \\
Number of sections & 58 & 56 & 57 \\
Number of texts & 41 & 17 & 29 \\
Ratio of text to content & 0.67 & 0.30 & 0.48 \\
Number of tasks & 142 & 117 & 129.5 \\
Ratio of tasks to content & 2.33 & 2.09 & 2.21 \\
\hline
\end{tabular}




\subsection{Science Textbooks}

Fourth Grade The structural setup of the two grade 4 science textbooks is quite similar in terms of the number of content pages, chapters and sections (see Table 11). Considering the number of texts and the text ratio, it is obvious that the book by Barnitzky et al. (2011) includes more texts as the book by Bertsch et al. (2016). The latter textbook often provides readers with short passages of no more than four sentences and also offers more pictures.

In both grade 4 science textbooks, the learning goal most frequently identified was 'conceptual knowledge' (see Table 12). The learning goal 'critical thinking' occupies a relatively minor position (at a frequency level of approx. 3 to 5\%) despite the fact that local history and some topics of social criticism are covered in the fourth grade science and social studies curriculum using the same textbooks.

The most frequent text type found in the grade 4 science textbooks was expository text (see Table 13).

In the textbooks, only $94.12 \%$ of the texts had no clear and unambiguous text structure. In three times, the text structure 'sequence' was identified, the text structure 'description' only once (see Table 14).

In terms of the instructional strategies, 'activating background knowledge' was the most frequent instructional strategy in the two textbooks, followed by 'relevance to self' and 'elaborate on a topic' (see Table 15). More than half of the tasks were identified

Table 12 Numbers and percentages for learning goals in grade 4 science textbooks

\begin{tabular}{|c|c|c|c|c|c|}
\hline \multirow[t]{2}{*}{ Learning goal } & \multicolumn{2}{|c|}{$\begin{array}{l}\text { Bartnitzky } \\
\text { et al. } 2011\end{array}$} & \multicolumn{2}{|c|}{$\begin{array}{l}\text { Bertsch et al. } \\
2016\end{array}$} & \multirow{2}{*}{$\begin{array}{l}\text { Average } \\
\text { both books } \\
\%\end{array}$} \\
\hline & $\mathrm{N}$ & $\%$ & $\mathrm{~N}$ & $\%$ & \\
\hline Conceptual knowledge & 46 & 79.31 & 34 & 60.71 & 70.01 \\
\hline Critical thinking & 3 & 5.17 & 2 & 3.57 & 4.37 \\
\hline Other & 9 & 15.52 & 20 & 35.71 & 25.62 \\
\hline
\end{tabular}

\begin{tabular}{lllllll}
\hline Text type & \multicolumn{2}{l}{$\begin{array}{l}\text { Bartnitzky et al. } \\
2011\end{array}$} & & \multicolumn{2}{l}{ Bertsch et al. 2016 } & $\begin{array}{l}\text { Average } \\
\text { both books }\end{array}$ \\
\cline { 2 - 3 } & $\mathrm{N}$ & $\%$ & & $\mathrm{~N}$ & $\%$ & $\%$ \\
\hline Expository & 37 & 90.24 & & 15 & 88.24 & 89.24 \\
Narrative & 4 & 9.76 & & 1 & 5.88 & 7.78 \\
Other & 0 & 0 & & 1 & 5.88 & 2.94 \\
\hline
\end{tabular}

\begin{tabular}{|c|c|c|c|c|c|}
\hline \multirow[t]{2}{*}{ Text structure } & \multicolumn{2}{|c|}{$\begin{array}{l}\text { Bartnitzky et al. } \\
2011\end{array}$} & \multicolumn{2}{|c|}{$\begin{array}{l}\text { Bertsch et al. } \\
2016\end{array}$} & \multirow{2}{*}{$\begin{array}{l}\text { Average } \\
\text { both books } \\
\%\end{array}$} \\
\hline & $\mathrm{N}$ & $\%$ & $\mathrm{~N}$ & $\%$ & \\
\hline Sequence & 2 & 3.92 & 1 & 5.88 & 4.9 \\
\hline Description & 1 & 1.96 & 0 & 0 & 0.98 \\
\hline No text structure & 48 & 94.12 & 16 & 94.12 & 94.12 \\
\hline
\end{tabular}

Table 14 Numbers and percentages for texts with a text structure in grade 4 science textbooks
Table 13 Numbers and percentages for text types in grade 4 science textbooks 
Table 15 Numbers and percentages for instructional strategies in grade 4 science textbooks

\begin{tabular}{|c|c|c|c|c|c|}
\hline \multirow[t]{2}{*}{ Instructional strategy } & \multicolumn{2}{|c|}{ Bartnitzky et al. 2011} & \multicolumn{2}{|c|}{ Bertsch et al. 2016} & \multirow{2}{*}{$\begin{array}{l}\text { Average } \\
\text { both books } \\
\%\end{array}$} \\
\hline & $\mathrm{N}$ & $\%$ & $\mathrm{~N}$ & $\%$ & \\
\hline Activating background knowledge & 23 & 16.20 & 13 & 11.11 & 13.66 \\
\hline Utility/ Relevance to self & 15 & 10.56 & 12 & 10.26 & 10.41 \\
\hline Elaborate on a topic & 18 & 12.68 & 9 & 7.69 & 10.19 \\
\hline Generate inferences & 7 & 4.93 & 3 & 2.56 & 3.48 \\
\hline Sequence & 1 & 0.70 & 2 & 1.71 & 1.21 \\
\hline Compare \& Contrast & 2 & 1.41 & 1 & 0.85 & 1.13 \\
\hline Direct retrieval of facts & 0 & 0 & 2 & 1.71 & 0.86 \\
\hline Other & 76 & 53.52 & 75 & 64.10 & 58.81 \\
\hline
\end{tabular}

Table 16 Structural setup of grade 6 science textbooks

\begin{tabular}{llll}
\hline & $\begin{array}{l}\text { Schermaier \& } \\
\text { Weislö 2013 }\end{array}$ & $\begin{array}{l}\text { Drexler } \\
\text { et al. 2016 }\end{array}$ & $\begin{array}{l}\text { Aver- } \\
\text { age both } \\
\text { books }\end{array}$ \\
\hline Number of content pages & 132 & 137 & 134.5 \\
Number of chapters & 4 & 4 & 4 \\
Number of sections & 29 & 30 & 29.5 \\
Number of texts & 102 & 164 & 133 \\
Ratio of text to content & 0.77 & 1.19 & 0.98 \\
Number of tasks & 62 & 171 & 116.5 \\
Ratio of tasks to content & 0.47 & 1.30 & 0.89 \\
\hline
\end{tabular}

\begin{tabular}{lllllll}
\hline Learning goal & $\begin{array}{l}\text { Schermaier \& } \\
\text { Weislö 2013 }\end{array}$ & $\begin{array}{l}\text { Drexler et al. } \\
2016\end{array}$ & $\begin{array}{l}\text { Aver- } \\
\text { age both } \\
\text { books }\end{array}$ \\
\cline { 2 - 3 } \cline { 5 - 6 } & $\mathrm{N}$ & $\%$ & & $\mathrm{~N}$ & $\%$ & $\begin{array}{l}\% \\
\%\end{array}$ \\
\hline Conceptual knowledge & 29 & 100 & 30 & 100 & 100 \\
\hline
\end{tabular}

Table 17 Numbers and percentages for learning goals in grade 6 science textbooks

as addressing some other instructional strategy, e.g., role play/ experiment/ exhibition ('other').

Sixth Grade A comparison of the structural setup found in the grade 6 and grade 4 science texts reveals clear similarities. For example, at both grade levels the number of content pages, chapters, and sections in the two books are very similar (see Table 16). However, there is a clear divergence in the sixth grade textbooks concerning the number of texts and the text ratio. The book by Drexler et al. (2016) contains more texts and shows the highest text ratio compared to any other textbook included in the analysis.

The only learning goal identified in the grade 6 science textbooks was 'conceptual knowledge' (see Table 17).

All of the texts in these books were identified as being 'expository' (see Table 18). 
Table 18 Numbers and percentages for text types in grade 6 science textbooks

Table 19 Numbers and percentages for texts with a text structure in grade 6 science textbooks

\begin{tabular}{|c|c|c|c|c|c|}
\hline \multirow[t]{2}{*}{ Text type } & \multicolumn{2}{|c|}{$\begin{array}{l}\text { Schermaier \& } \\
\text { Weislö } 2013\end{array}$} & \multicolumn{2}{|c|}{ Drexler et al. 2016} & \multirow{2}{*}{$\begin{array}{l}\text { Aver- } \\
\text { age both } \\
\text { books } \\
\%\end{array}$} \\
\hline & $\mathrm{N}$ & $\%$ & $\mathrm{~N}$ & $\%$ & \\
\hline Expository & 102 & 100 & 164 & 100 & 100 \\
\hline
\end{tabular}

\begin{tabular}{|c|c|c|c|c|c|}
\hline \multirow[t]{2}{*}{ Text structure } & \multicolumn{2}{|c|}{$\begin{array}{l}\text { Schermaier \& } \\
\text { Weislö } 2013\end{array}$} & \multicolumn{2}{|c|}{$\begin{array}{l}\text { Drexler et al. } \\
2016\end{array}$} & \multirow{2}{*}{$\begin{array}{l}\text { Average } \\
\text { both books } \\
\%\end{array}$} \\
\hline & $\mathrm{N}$ & $\%$ & $\mathrm{~N}$ & $\%$ & \\
\hline Description & 1 & 0.98 & 18 & 10.98 & 5.98 \\
\hline Sequence & 1 & 0.98 & 0 & 0 & 0.49 \\
\hline Comparison & 1 & 0.98 & 0 & 0 & 0.49 \\
\hline No text structure & 99 & 97.06 & 146 & 89.02 & 93.04 \\
\hline
\end{tabular}

Table 20 Numbers and percentages of instructional strategies in grade 6 science textbooks

\begin{tabular}{|c|c|c|c|c|c|}
\hline \multirow[t]{2}{*}{ Instructional strategy } & \multicolumn{2}{|c|}{$\begin{array}{l}\text { Schermaier \& Weislö } \\
2013\end{array}$} & \multicolumn{2}{|c|}{ Drexler et al. 2016} & \multirow{2}{*}{$\begin{array}{l}\text { Average } \\
\text { both books } \\
\%\end{array}$} \\
\hline & $\mathrm{N}$ & $\%$ & $\mathrm{~N}$ & $\%$ & \\
\hline Direct retrieval of facts & 29 & 46.77 & 72 & 42.11 & 44.44 \\
\hline T-chart & 9 & 14.52 & 3 & 1.75 & 8.14 \\
\hline Generate inferences & 2 & 3.23 & 19 & 11.11 & 7.17 \\
\hline Activating background knowledge & 2 & 3.23 & 8 & 4.68 & 3.96 \\
\hline Elaborate on a topic & 0 & 0 & 11 & 6.43 & 3.22 \\
\hline Utility/ Relevance to self & 0 & 0 & 10 & 5.85 & 2.93 \\
\hline Sequence & 1 & 1.61 & 4 & 2.34 & 1.98 \\
\hline Compare \& Contrast & 0 & 0 & 4 & 2.34 & 1.17 \\
\hline Explain vocabulary & 0 & 0 & 1 & 0.58 & 0.29 \\
\hline Other & 19 & 30.65 & 39 & 22.81 & 26.73 \\
\hline
\end{tabular}

Only about $7 \%$ of all texts counted in the two books were identified as having a specific text structure (see Table 19). Nearly all the identified text structures were 'description' and found in the Drexler et al. (2016) textbook.

In terms of the instructional strategies, 'direct retrieval of facts' was the most frequent instructional strategy (44.44\%) identified in the two grade 6 textbooks (see Table 20). Whereas the Drexler et al. (2016) textbook addresses the strategy 'generate inferences' frequently, the Schermaier and Weislö (2013) textbook focuses 'T-charts' more frequently. 


\section{Discussion}

\subsection{Structural Setup}

The present study analysed eight textbooks used in Austrian schools in order to investigate how they address reading comprehension.

Teaching reading comprehension involves texts. The present analysis shows how the relation of texts and tasks to the number of content pages differs from book to book. Across the books examined, the 'text load' was found to vary considerably. In the grade 4 language textbooks the ratio of text to content was quite similar (ranging from 0.41 to 0.58 ). For the grade 6 texts, this ratio was more diverse (ranging from 0.39 to 0.83 ). Thus, use of the grade 6 textbook by Pramper and Leb (2012) requires that students read more texts than are required when using the textbook by Bulling et al. (2016). In contrast, the latter textbook requires that students complete a comparatively higher number of tasks. For example, for Bulling et al. the ratio of tasks to content is 3.23, whereas for Pramper and Leb (2012) this ratio is only 1.85 . Thus, different demands are placed on the students depending on which book is used for teaching.

In subjects other than language lessons, texts provide the basis for learning content. The science textbooks analysed here make use of textual content to varying degrees. The grade 4 textbooks Bertsch et al. (2016) and Bartnitzky et al. (2011) showed text ratios of 0.3 and 0.67 , respectively. For the grade 6 texts these ratios were even higher, and the Drexler et al. (2016) textbook, with a figure of 1.19, was found to have the highest ratio of text to content of all eight books analysed. Hence, it would appear that three of the four science books rely heavily on texts. Although reading is not addressed explicitly in the textbooks, reading comprehension is clearly needed to access the content. When choosing a textbook, both for language lessons and for other subject areas, teachers need to be aware of the different amounts of text that students are required to work with. The use of a science textbook with a heavy bias towards textual content could serve to generate frustration, especially among the weaker readers in a class.

\subsection{Learning Goals}

In terms of the learning goals, the analysis revealed that three of the four language textbooks addressed reading comprehension more frequently than any other learning goal. Even in the fourth textbook (for grade 4, Freund et al. 2016), reading comprehension was addressed almost as often as the learning goals grammar and orthography. In contrast, the other grade 4 textbook by Koppensteiner et al. (2018), is specifically designed to address reading comprehension, and neglects the other elements of the official curriculum (e.g., grammar, orthography, writing; see BMBWF 2003). This is worth noting since teachers can individually decide which textbook they use in their class. Of course, they often choose one textbook from the list provided by the School Textbook Initiative, as these are free of charge. However, these books do seem to differ in terms of the learning goals they focus on. With respect to grade 6 textbooks, the difference between the textbooks' learning goals becomes even more obvious. Although the learning goal addressed most frequently by both grade 6 language texts is reading comprehension, the remaining goals are addressed in different ways by the two textbooks. Assuming that teachers wish to teach all aspects of the official language curriculum (as specified in BMBWF 2003, 2018, 2020), they need to know which textbook can be used to support each of these aspects most effectively. 
As pointed out earlier, it is not intended that reading comprehension be addressed solely in language lessons. The official decree on reading (BMBWF 2013) prescribes that reading instruction be cross-curricular and thus integrated within the teaching of other school subjects outside language instruction. Although the science textbooks analysed here were not originally designed to support reading comprehension, they still provide a useful resource when attempting to augment various reading strategies.

\subsection{Text Types}

According to the official statement concerning reading (BMBWF 2013), students need to engage with a variety of text types and genres, whereby expository texts are seen to be particularly important during the transition from primary to secondary level. The present analysis has only looked at text types, and not text genres. Unsurprisingly, the focus in science textbooks is mostly on expository texts (with figures varying from 88.24 to $100 \%$ ). In contrast, the language textbooks (at grade 4 and grade 6) address both expository and narrative texts. However, in three of these textbooks, narratives (figures ranging from 50 to $67.21 \%$, depending on the textbook) occur more frequently than expository texts (with respective figures ranging from 17.11 to $24.59 \%$ ). In contrast, one of the grade 4 language textbooks (Koppensteiner et al. 2018) showed exactly the opposite pattern (30\% narratives, $56.67 \%$ expository texts). Although all the language textbooks address different text types, it is important that teachers are aware of the text types that can and cannot be supported by a particular book.

\subsection{Text Structure}

Teachers are expected to incorporate reading strategy training as a part of their reading lessons (BMBWF 2013; Schabmann et al. 2012). One internationally recognised reading comprehension strategy entails focussing on text structure in order that students may identify the main facts (Hebert et al. 2016; Meyer 1975). Although this strategy is not common in Austria, one aim of the present analysis was to reveal whether current Austrian textbooks could potentially be used to teach this strategy. The results reveal that the texts analysed rarely address one specific text structure (based on Meyer's (1975) five text structures). Rather, the texts often involve more than one structure (e.g., descriptive elements, comparisons, and problems and solutions, can be present in one and the same text). However, in order to introduce text structure as part of teaching reading comprehension, it would probably be more appropriate to work with texts having one clearly defined structure, so that, for example, signalling words could be used to identify the structure of a text and provide a framework for understanding the content (Roehling et al. 2017). Thus, most of the texts analysed here do not appear useful in supporting teachers in instructing text structure strategies. When teaching the strategy of identifying and describing text structures, it seems that teachers are better served by relying on alternative materials.

\subsection{Instructional Strategies}

The textbook tasks presented in the books under analysis here were examined in terms of their instructional strategies and activities. The present study revealed that while the tasks in the language textbooks (compared to the science textbooks) cover a variety of different 
activities, the relative frequencies of the tasks employed vary from book to book. On a positive note, the analysis revealed that the processes involved in reading comprehension, at the different hierarchical levels as defined by PIRLS 2016 (Mullis \& Martin 2015) or PISA 2015 (OECD 2017), are also those activities identified most frequently in the language textbooks. These activities comprise 'direct retrieval of facts', 'elaborate on a topic' and 'generate inferences'. It thus appears that the language texts adequately address the processes entailed in reading comprehension. However, the balance of these processes varies depending on the book. For example, while three of the language textbooks are more likely to deal with tasks requiring direct retrieval of information, the grade 6 textbook by Pramper and Leb (2012) focuses relatively more on elaboration tasks.

While the results show that common reading strategies are partly supported during the activities described, the strategies are often not explicitly declared or introduced using stepby-step instructions for specific texts. Reading strategies, however, are an important tool in self-regulated reading (Philipp 2015), a competence of particular importance in subject matter areas based on independent knowledge acquisition. Reading strategies should and can be taught across disciplines (BMBWF 2013; Leisen 2007; Torgesen et al. 2007). Certainly, the systematic instruction and practice of strategies ought to be the primary responsibility of language/reading teachers, but teachers in other subject areas can and should both reinforce and elaborate upon the use of these strategies in class (Torgesen et al. 2007). This is also prescribed in official policy (see BMBWF 2013). More effective instruction and coordinated support of reading strategies across disciplines could probably improve the reading abilities of students. Teachers need not only to be aware of the effects of strategy training, but also to be capable of integrating strategy instruction into their lessons, whether this is present in current textbooks or not. This shows once again how important it is for teachers to be aware of what strategies textbooks can or cannot support.

As is only to be expected, the instructional strategies employed in the science textbooks varied depending on whether the textbooks addressed grade 4 or grade 6 classes. In the grade 4 books, the three tasks that were identified most frequently (i.e., activating background knowledge, elaborating on a topic, utility/ relevance to self) were tasks that involve activities outside a specific text. Often these tasks can be solved by those lacking full understanding of the text. Thus, even for students with reading comprehension deficits, the processing of such tasks may not entail too much stress. In contrast, the analysis here reveals that the most frequent tasks in the grade 6 science textbooks are closely linked to corresponding texts and, in this way, are based on reading comprehension (e.g., direct retrieval of facts, generating inferences). This result reinforces the assumption, at least as far as science textbooks are concerned, that reading comprehension skills are a clear prerequisite for knowledge acquisition.

\subsection{Limitations of the Current Study}

However, there are a few limitations of the present analysis which need to be noted. First, the analysis was not capable of providing a clear picture concerning the differences between language and science textbooks, on the one hand, and between fourth- and sixth-grade textbooks on the other hand. This is probably partly due to the limited number of textbooks analysed. To ascertain whether the results are generalizable, the analysis needs to be extended to cover a larger sample of textbooks. Second, the predefined categories (decided upon in the international researcher team for reasons of comparability) limited the informational value of the data, especially given the case that some texts and tasks needed to be assigned to the option "other". A future study employing categories and options more adapted to the textbooks 
used in Austria would probably provide a clearer picture. Third, within the present study, in addition to the work of the author, who analysed all eight textbooks in their entirety, lack of resources meant that for purposes of verification only two chapters of each textbook could be further analysed by two students. To strengthen the reliability of the analysis, future studies ought to use a more extensive data sample for verification purposes.

\section{Conclusion}

Given the variety of textbooks available in Austrian schools, teachers need to take a closer look at a particular textbook before using it in class. As this study demonstrates, textbooks vary considerably, not only in the amount of text they contain, but also in terms of their respective learning goals, instructional strategies, and required activities. Since textbooks are often relied upon as one of the most supportive instruments in teaching, teachers need to be aware that the chosen textbook may not automatically cover the content that needs to be delivered. This is particularly true for strategy training in reading comprehension (Schabmann et al. 2012). Such training is not embedded in the textbooks and needs to be taught additionally. In addition to this, it is also well known that in order to enhance student reading comprehension, strategy training needs to be reinforced in content lessons and not just in language lessons (see BMBWF 2013; Leisen 2007).

This study has clear implications for teacher training. On the one hand, teachers need instruction on how didactic and pedagogical considerations may be relevant when selecting specific texts from the range of approved textbooks available. On the other hand, they also need to be trained in the use of textbooks in the classroom (Fuchs et al. 2014). In this way, teachers would become capable of using textbooks in their teaching more as a source of support than as a source of dependence.

Acknowledgements This study is part of a comparative investigation of textbooks in different European countries based on a collaboration in the European Literacy Network (COST Action 1401).

Funding Open Access funding was provided by University of Graz.

Open Access This article is licensed under a Creative Commons Attribution 4.0 International License, which permits use, sharing, adaptation, distribution and reproduction in any medium or format, as long as you give appropriate credit to the original author(s) and the source, provide a link to the Creative Commons licence, and indicate if changes were made. The images or other third party material in this article are included in the article's Creative Commons licence, unless indicated otherwise in a credit line to the material. If material is not included in the article's Creative Commons licence and your intended use is not permitted by statutory regulation or exceeds the permitted use, you will need to obtain permission directly from the copyright holder. To view a copy of this licence, visit http://creativecommons.org/licenses/by/4.0/.

\section{References}

Aaron, P. G., Joshi, R. M., Boulware-Gooden, R., \& Bentum, K. (2008). Diagnosis and treatment of reading disabilities based on the component model of reading: An alternative to the discrepancy model of learning disabilities. Journal of Learning Disabilities, 41, 67-84.

COST Action IS1401 Members. (2018). 'Textbook analysis'. In Meeting minutes of Working Group Two. November, 2nd. University of Porto, Portugal, Boardroom

Akhondi, M., Malayeri, F. A., \& Samad, A. A. (2011). How to teach expository text structure to facilitate reading comprehension. The Reading Teacher, 64(5), 368-372.

Bartnitzky, H., Bunk, H.-D., Pölzl, A., \& Stessel-Hermanek, M. (2011). Lasso Sachbuch 4. Wien: ÖBV. 
Beerwinkle, A. L., Wijekumar, K., Walpole, S., \& Aguis, R. (2018). An analysis of the ecological components within a text structure intervention. Reading and Writing, 31, 2041-2064.

*Bertsch, C., Eichhorn, S., \& Ludwig-Szeni, S. (2016). Sachunterricht Sonnenklar! 3/4. Schülerbuch Teil B. Wien: ÖBV.

BMBWF (Austrian Federal Ministry of Education, Science and Research). (2003). Volksschullehrplan. Deutsch, Lesen, Schreiben [Primary school curriculum. German, reading, writing].https://www.bmbwf .gv.at/Themen/schule/schulpraxis/lp/lp_vs.html.

BMBWF (Austrian Federal Ministry of Education, Science and Research). (2013). Grundsatzerlass Leseerziehung [Principal decree on reading education]. https://bildung.bmbwf.gv.at/schulen/unterricht/prinz/ leseerziehung_ge.pdf?61edl1.

BMBWF (Austrian Federal Ministry of Education, Science and Research). (2018). Lehrplan der Neuen Mittelschule [Curriculum of the New Middle school]. https://www.bmbwf.gv.at/Themen/schule/schulpraxi s/lp/lp_nms.html.

BMBWF (Austrian Federal Ministry of Education, Science and Research). (2020). Lehrplan der Allgemeinbildenden Höheren Schulen [Curriculum of the General Secondary School].https://www.bmbwf.gv.at/ Themen/schule/schulpraxis/lp/lp_ahs.html.

Breit, S., Bruneforth, M., \& Schreiner, C. (Eds.). (2016). Standardüberprüfung 2015 Deutsch/Lesen/Schreiben, 4. Schulstufe [Educational standards testing 2015 German/reading/writing, 4th grade]. Bundesergebnisbericht. Salzburg: BIFIE.

*Bulling, P., Seli, M., Strömer, I., \& Thaler, M. (2016). Starke Seiten Deutsch 2. Sprachbuch. Wien: ÖBV.

COST. (2019). IS1401 Strengthening Europe's capabilities by establishing the European literacy network. Retrieved fromhttps://www.cost.eu/actions/IS1401/tabs\#Name:overview

Doll, J., \& Rehfinger, A. (2012). Historische Forschungsstränge der Schulbuchforschung und aktuelle Beispiele empirischer Schulbuchwirkungsforschung Historical Research Strands of Textbook Research and Current Examples of Empirical Textbook Effects Research. In J. Doll, K. Frank, D. Fickermann, \& K. Schwippert (Eds.), Schulbücher im Fokus Nutzungen, Wirkungen und Evaluation (pp. 6-31). Waxmann: Münster.

*Drexler, M., Grössing, H., \& Hellerschmidt, B. (2016). Biologie für alle, 2. Klasse. Wien: Olympe.

*Freund, J., Jarolim, F., Ackerlauer, P., Bailicz, I., \& Prcha, I. (2016). Deutsch 4. Sprach-Lese-Buch mit differenzierten Übungen. Teil A und Teil B. Wien: ÖBV.

Fuchs, E., Niehaus, I., \& Stoletzki, A. (2014). Das Schulbuch in der Forschung. Analysen und Empfehlungen für die Bildungspraxis [The textbook in research. Analyses and recommendations for educational practice]. Göttingen: V\&R unipress.

Hebert, M., Bohaty, J. J., Nelson, J. R., \& Brown, J. A. (2016). The effects of text structure instruction on expository reading comprehension: A meta-analysis. Journal of Educational Psychology, $108(5), 609-629$.

Heinze, C. (2005). Das schulbuch zwischen lehrplan und unterrichtspraxis zur einführung in den themenband the textbook between curriculum and teaching practice. In E. Matthes \& C. Heinze (Eds.), Das Schulbuch zwischen Lehrplan und Unterrichtspraxis (pp. 9-17). Klinkhardt: Bad Heilbrunn.

Irez, S. (2009). Nature of science as depicted in Turkish biology textbooks. Science Education, 93(3), $422-447$.

Joshi, R. M., \& Aaron, P. G. (2011). Assessment of reading problems among ELLs based on the component model. In A. Durgunoglu \& C. Goldenberg (Eds.), Language and literacy development in bilingual settings (pp. 304-331). New York, NY: Guilford.

Joshi, R. M., Binks, E., Graham, L., Ocker-Dean, E., Smith, D. L., \& Boulware-Gooden, R. (2009). Do textbooks used in university reading education courses conform to the instructional recommendations of the National Reading Panel? Journal of Learning Disabilities, 42, 458-463.

Kahl, D. (2000). Zehn thesen zum umgang mit dem lehrwerk [Ten theses on dealing with the textbook]. In R. Fery \& V. Raddatz (Eds.), Lehrwerke und ihre Alternativen (pp. 125-128). Frankfurt am Main: PeterLang.

Klicpera, C., \& Gasteiger-Klicpera, B. (1993). Lesen und Schreiben - Entwicklung und Schwierigkeiten: Die Wiener Längsschnittuntersuchungen über dien Entwicklung, den Verlauf und die Ursachen von Lese- und Schreibschwierigkeiten in der Pflichtschulzeit [Reading and Writing - Development and Difficulties: The Vienna Longitudinal Studies]. Bern: Huber Verlag.

Knight, B. A. (2013). Textbooks in the digital age. Cogent Education, 2(1), 1015812. https://doi. org/10.1080/2331186X.2015.1015812.

*Koppensteiner, C., Meixner, C., \& Figl, U. (2018). Lese- und Lernprofi 4. Sinnerfassend lesen lernen mit Julia und Michael, den Leseprofis. Wien: BVL. 
Landerl, K., \& Wimmer, H. (2008). Development of word reading fluency and spelling in a consistent orthography: An 8-year follow-up. Journal of Educational Psychology, 100(1), 150-161.

Leisen, J. (2007). Lesen und verstehen lernen-strategien und prinzipien zur arbeit mit sachtexten im unterricht [Learning to read and understand-strategies and principles for working with factual texts in the classroom]. Pädagogik, 6, 7-12.

Maijala, M., \& Tammenga-Helmantel, M. (2017). Grammar exercises in Dutch, Finnish and global textbooks for teaching German as a foreign language. The Language Learning Journal, 47, 537-557.

Meyer, B. J. F. (1975). The organization of prose and its effects on memory. Amsterdam: North -Holland.

Miles, M. B., \& Huberman, A. M. (1994). Qualitative data analysis: An expanded sourcebook (2nd ed.). Thousand Oaks, London, New Dehli: Sage Publications

Mullis, I. V. S., \& Martin, M. O. (Eds.). (2015). PIRLS 2016 Assessment Framework. $2^{\text {nd }}$ ed. Chestnut Hill, MA: TIMSS \& PIRLS International Study Center, Boston College.

Mullis, I. V. S., Martin, M. O., Kennedy, A. M., Trong, K. L., \& Sainsbury, M. (2009). PIRLS 2011 assessment framework. Chestnut Hill, MA: TIMSS \& PIRLS International Study Center, Boston College.

Nicol, C. C., \& Crespo, S. M. (2006). Learning to teach with mathematics textbooks: How preservice teachers interpret and use curriculum materials. Educational Studies in Mathematics, 62(3), 331-355.

OECD. (2017). PISA 2015 Assessment and Analytical Framework. OECD publishing. Retrieved fromhttps://read.oecd-ilibrary.org/education/pisa-2015-assessment-and-analytical-framework/pisa2015-reading-framework_9789264281820-4-en\#page1.

Perfetti, C. A., Landi, N., \& Oakhill, J. (2005). The acquisition of reading comprehension skill. In M. J. Snowling \& C. Hulme (Eds.), The Science of Reading: A Handbook (pp. 227-247). Oxford: Blackwell.

Philipp, M. (2015). Lesestrategien. Bedeutung, Formen und Vermittlung [Reading strategies. Meaning, forms and mediation]. Weinheim: Beltz Juventa.

*Pramper, W., \& Leb, M. (2012). Deutschstunde 2. Das Sprach- und Lesebuch. Teil 1 und Teil 2. Linz: Veritas.

Richards, J. C. (2014). The ELT textbook. In S. Garton \& K. Graves (Eds.), International Perspectives on Materials in ELT (pp. 19-36). Basingstoke, UK: Palgrave Macmillan.

Roehling, J. V., Hebert, M., Nelson, J. R., \& Bohaty, J. J. (2017). Text structure strategies for improving expository reading comprehension. The Reading Teacher, 71(1), 71-82.

Roth, K. J., Druker, S. L., Garnier, H. E., Lemmens, M., Chen, C., Kawanaka, T., Rasmussen, D., et al. (2006). Teaching Science in Five Countries: Results from the TIMSS 1999. NCES 2006-011.

Schabmann, A., Landerl, K., Bruneforth, M., \& Schmidt, B. M. (2012). Lesekompetenz leseunterricht und leseförderung im österreichischen schulsystem analysen zur pädagogischen förderung der lesekompetenz reading competence, reading instruction and reading promotion in the Austrian school system. In B. Herzog-Punzenberger (Ed.), Nationaler Bildungsbericht Österreich (Vol. 2, pp. 17-69). Leykam: Graz.

Schermaier, A., \& Weislö, H. (2013). bio@school 2 (4th ed.). Linz: Veritas.

Schmich, J., Breit, S., Lanzdorf, R., \& Itzlinger-Bruneforth, U. (2017). Schulischer kontext: Leseunterricht, fortbildung und schulressourcen school context: Reading lessons, training and school resources. In C. Wallner-Paschon, U. Itzlinger-Bruneforth, \& C. Schreiner (Eds.), PIRLS 2016 Die Lesekompetenz am Ende Der Volksschule (pp. 83-101). Leykam: Graz.

Schwantner, U., \& Schreiner, C. (Eds.). (2010). PISA 2009. Internationaler vergleich von schülerleistungen [PISA 2009: International comparison of student performance]. Graz: Leykam.

Stern, L., \& Roseman, J. (2004). Can middle school science textbooks help students learn important ideas? Findings from Project 2061's curriculum evaluation study: Life science. Journal of Research in Science Teaching, 41(6), 538-568.

Torgesen, J. K., Houston, D. D., Rissman, L. M., Decker, S. M., Roberts, G., Vaughn, S., et al. (2007). Academic literacy instruction for adolescents: A guidance document from the center on instruction. Portsmouth, NH: RMC Research Corporation, Center on Instruction.

Valverde, G. A., Bianchi, L. J., Wolfe, R., Schmidt, W. H., \& Houang, R. T. (2002). According to the book. using TIMSS to investigate the translation of policy into practice through the world of textbooks. Dordrecht: Kluwer.

Van den Ham, A.-K., \& Heinze, A. (2018). Does the textbook matter? longitudinal effects of textbook choice on primary school students' achievement in mathematics. Studies in Educational Evaluation, $59,133-140$

Wallner-Paschon, C., Itzlinger-Bruneforth, U., \& Schreiner, C. (Eds.). (2017). PIRLS 2016. Die Lesekompetenz am Ende der Volksschule [PIRLS 2016: The reading competence at the end of primary school]. Graz: Leykam. 
Wijekumar, K., Meyer, B. J. F., \& Lei, P. (2017). Web-based text structure strategy instruction improves seventh graders' content area reading comprehension. Journal of Educational Psychology, 109(6), $741-760$.

Publisher's Note Springer Nature remains neutral with regard to jurisdictional claims in published maps and institutional affiliations. 